\title{
“KEPO MBAH KUPIS"KRIPIK OLAHAN DARI LIMBAH KULIT PISANG CAMILAN BERANEKA RASA
}

\author{
Moh Amiruddin ${ }^{1}$, Moh Rozek ${ }^{2}$, Sulistiyanto ${ }^{3}$ \\ Teknik Elektro, Fakultas Teknik, Universitas Nurul Jadid \\ Karang Anyar Paiton Probolinggo 67291 \\ mohamiruddin93@gmail.com ${ }^{1}, \underline{\text { mohrozek15@gmail.com }}^{2}$, sulistiyanto@gmail.com ${ }^{3}$
}

\begin{abstract}
ABSTRAK
KEPO MBAH KUPIS (Kripik Olahan Dari Limbah Kulit Pisang Camilan Beraneka Rasa) adalah satu bentuk kreasi unik dari limbah kulit pisang yang akan di buat menjadi olahan kripik. Pisang adalah salah satu buah yang sangat di gemari oleh masyarakat, tapi di kalangan masyarakat probolinggo belum banyak mengerti manfaat dari kulit pisang itu selain buahnya. Kulit pisang merupakan hasil samping dari pemanfaatan pisang yang dapat dijadikan makanan ringan seperti kripik kulit pisang.Walaupun kulit pisang merupakan hasil samping, namun kandungan gizinya takkalah dari buahnya. Kulit pisang mengandung serat yang cukup tinggi, vitamin $\mathrm{C}$, B, kalsium, protein, dan karbohidrat. Di berbagai tempat sangat mudah untuk menemukan kulit pisang seperti dari usaha olahan pisang yang kulitnya bisa di manfaatkan lagi menjadi kripik.Untuk itu, kami sebagai mahasiswa mempunyai inovasi baru agar kripik kulit pisang bisa menjadi makanan ringan yang paling ditunggu-tunggu kehadirannya. "KEPO MBAH KUPIS" merupakan keripik pisang dengan berbagai macam rasa untuk menggugah selera masyarakat akan makanan ringan. Selain itu juga didukung dengan kemudahan memasarkan produkdijualke toko kelontong, media online dan Even-even Campus
\end{abstract}

Kata Kunci: limbah kulit pisang, camilan beraneka rasa

\begin{abstract}
KEPO MBAH KUPIS (Processed Chips From Banana Skin Waste Various Flavored Snacks) is a unique form of banana peel waste that will be made into chips. Bananas are one of the fruits that are loved by the community, but in the community of Probolinggo they do not understand the benefits of banana peels besides the fruit. Banana skin is a byproduct of the use of bananas that can be used as snacks such as banana peel chips. Although banana peels are a by-product, the nutritional content is not inferior to the fruit. Banana skin contains high fiber, vitamin $C, B$, calcium, protein, and carbohydrates. In various places it is very easy to find banana peels, such as from processed bananas whose skin can be used again as chips. For this reason, we as students have new innovations so that the chips of banana skin can be the most eagerly awaited presence. "KEPO MBAH KUPIS" is a banana chips with various flavors to arouse people's appetite for snacks. In addition, it is also supported by the ease of marketing products sold to grocery stores, online media and Campus Events
\end{abstract}

Keywords: banana peel waste, various flavored snacks 


\section{PENDAHULUAN}

Pisang adalah salah satu buah yang sangat di gemari oleh masyarakat, tapi di kalangan masyarakat indonesia belum banyak mengerti manfaat dari kulit pisang itu selain buahnya, kulit pisang biasanya menjadi limbah yang di buat makanan ternak. Kandungan yang ada di dalam buah pisang jauh lebih tinggi dari apel. (Augesti, 2018). Kulit pisang sendiri juga dapat kita olah menjadi keripik yang enak dan gurih.Kulit pisang merupakan hasil samping dari pemanfaatan pisang yang dapat dijadikan makanan ringan seperti kripik kulit pisang.Walaupun kulit pisang merupakan hasil samping, namun kandungan gizinya takkalah dari buahnya.Kulit pisang mengandung serat yang cukup tinggi, vitamin $\mathrm{C}, \mathrm{B}$, kalsium, protein, dan karbohidrat. Kandungan gizi pada pisang ini sangat banyak sehingga sangat baik untuk di konsumsi masyarakat. (Kurniawan, 2018). Di berbagai tempat sangat mudah untukmenemukan kulit pisang seperti dari usaha olahan pisang yang kulitnya bisa di manfaatkan lagi menjadi kripik. Untuk itu, kami sebagai mahasiswa mempunyai inovasi baru agar kripik kulit pisang bisa menjadi makanan ringan yang paling ditunggu-tunggu kehadirannya. Oleh karena adanya peluang usaha yang bagus di bidang kuliner olahan makanan ringan, maka kami berencana membuat "KEPO MBAH KUPIS" yang merupakan keripik pisang dengan berbagai warna dan rasa untuk menggugah selera sebagai daya tarik masyarakat akan makanan ringan ini.

Berdasarkan latar belakang tersebut, output yang kami harapkan dari pengabdian ini adalah sebagai berikut:

1. Bagaimana cara mengelola kuliat pisang.

2. Apa saja yang diperlukan pembuatan keripik kulit pisang.

3. Bagaimana proses pembuatannya.

4. Bagaimana cara memasarkan produk yang telah dibuat.

Pengabdian masyarakat ini memiliki tujuan:

Kegiatan yang akan dilaksanakan ini memiliki tujuan :

1. Menghasilkan keripik kulit pisang yang bernilai jual tinggi.

2. Meningkatkan daya kreativitas dan jiwa kewirausah an mahasiswa.

3. Membuka peluang usaha baru di bidang kuliner.

4. Meningkatkan pendapatan masyarakat.

5. Mengurangi limbah kulit pisang. 


\section{METODE}

Pelaksanaan Program Kreatifitas Mahasiswa (PKM) sesuai dengan rencana, yang meliputi tahapan (1) Persiapan. Suatu Kondisi yang memberi kemudahan kepada Mitra untuk memunculkan kreativitasnya. Ini diperoleh dengan, mendengar keluhan mitra, menampung ide-ide kreatif mitra, (2) Praktek langsung: Metode ini dilakukan dengan cara, mengajarkan Mitra cara menggunakan Intenet Marketing membuat kripik dari kulit pisang, dan bagaimana memasarkan produk dari kripik tersebut, yang dilatih oleh orangorang yang professional dibidangnya. (3) Self training: Metode ini dilakukan untuk Mitra, agar mitra mengerjakan tugas-tugas yang diberikan oleh instruktur pengelolaan kulit pisang menjadi kripik pisang dengan macam rasa, sebagai test case. (4) Implementation. Mulai mentransformasi ide menjadi kenyataan dan digunakan. Disini mitra mulai mengimplementasikan dan membidik target pasar mana yang akan dituju. (5) Evaluasi. Langkah ini merupakan kegiatan untuk mengetahui "nilai lebih" dari hasil kreativitas yang dilakukan. Mengevaluasi dari hasil impelementasi yang dilakukan oleh Mitra, apakah masih ada yang perlu diperbaiki dan bagamaimana caranya? (6) Pengembangan. Semua pada pertanyaan yang dikemukakan langkah evaluasi merupakan bahan untuk pengembangan.

\section{HASIL DAN PEMBAHASAN}

\section{Menjadikan kripik kulit pisang sebagai khas makanan daerah}

Keripik kulit pisangsebenarnya rasanya tidak kalah lezat dari kripik pasaran yang di jual kebanyakan dan kami berharap dari hasil kreatifitas ini menjadikan kripik kulit pisang senagai makanan khas daerah yang wajib untuk dicicipi.

\section{Camilan unik dan mudah dicari}

Nilai positif usaha ini adalah belum adanya usaha sejenis di daerah Paiton, sehingga produk ini belum memiliki kompetitor yang memiliki kesamaan produk dengan produk kami. Selain itu juga didukung dengan kemudahan memasarkan prudok karena dapat dititipkan di toko kelontong atau warung.

\section{Tahapan Pemasaran}

Strategi pemasaran yang kami terapkan adalah dengan harganya yang murah,tapidengankualitas produk keripik kulit pisang yang baik, dan promosi kepada temanteman dan kerabat. 


\section{Strategi Produk}

Strategi produk dilakukan dengan upaya diversifikasi terhadap produk yang dihasilkan. Diversifikasi merupakan hasil inovasi yang patut ditelaah lebih jauh. Dalam hal ini dimungkinkan adanya penambahan dan pengembangan rasa dan bentuk untuk meningkatkan kualitas produk.

\section{Strategi Harga}

Strategi harga kami lakukan berdasarkan harga pasar, harga produkyang ditetapkan adalah standar harga pasar, atau dengan kata lain harga produk kami bersaing dan tidak merusak harga pasar, untuk satu kemasan produk 'KEPO BHAH KUPIS' dengan harga Rp7.000, untuk 100gram dan yang 150gram denganhargaRp 10.000. Dalam memperluas pemasarannya maka diperlukan kerjasama dengan penyalur untuk menyampaikan produknya ke konsumen. Kerjasama tersebut dilakukan dengan penyalur-penyalur pihak pemilik warung dan toko-toko kelontong,kerjasama juga dapat dilakukan dengan pihak kampus

\section{Peralatan Dan Bahan}

Produk ini menggunakan berbagai macam bahan-bahan yang digunakan sebagai alat proses pembuatan Kripik olahan limbah dari kulit pisang beraneka rasa.Perlatan atau bahan yang dibutuhkan juga digunakan untuk menjamin kelancaran proses pembuatan ini.

Produk ini menggunakan Peralatan-peralatan yang dibutuhkansebagai berikut:
1. Kompor Gas
9. Spatula
2. Gas Elpiji
10. Saringan
3. BaskomBesar
11. Tampah
4. Bakbesar
12. Telenan
5. Gayung
13. Plastik $250 \mathrm{~g}$
6. Sendok
14. Timbangan
7. Wajan
15. Pisau
8. Serbet
16. Peralatan
tempat usaha

Produk ini menggunakan bahan-bahan habis pakai sebagai berikut:
1. Kulit pisang
5. Tepung beras
2. Gula pasir
6. Minyak goreng
3. Air kapur sirih
7. Bumbu tabur 

4. Garam
aneka rasa

\section{Proses Produksi}

Urutan kegiatan pembuatan kripik kulit pisang ditampilkan pada Gambar 1.
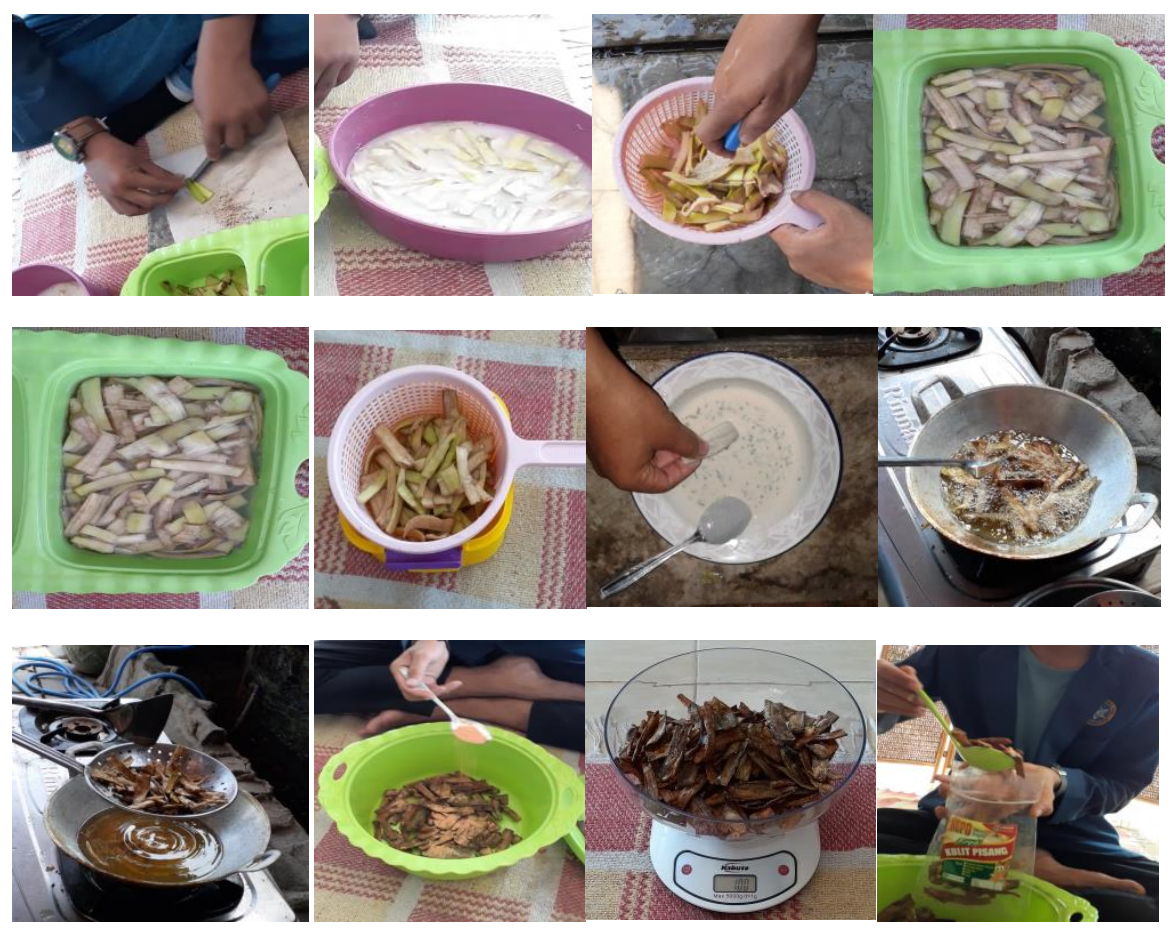

Gambar 1. Urutan langkah-langkah pembuatan kripik kulit pisang

1. Siapkan kulit pisang

2. Potong kulit pisang dan iris tipis kulit pisang diambil bagian kulit bagian dalamnya

3. Rendam kulit pisang di dalam larutan air kapur sirih perbandingan 1 liter air dicampur 2 sendok kapur sirih.-+ 20 menit, lalu angkat.

4. Dicuci sampai bersih

5. Rendam kulit pisang di dalam larutan air garam perbandingan 1 liter air dicampur 1 sendok garam.-- 20 menit, lalu angkat.

6. Selanjutnya rendam kulit pisang di dalam larutan air gula perbandingan 1 liter air dicampur 3 sendok gula -+ 20 menit, lalu angkat.

7. Ditiriskan -+15 menit, untuk mengurangi kadar air setelah perendaman.

8. Dicelupkan keadonan tepung beras

\section{Bahan untuk pencelup :}

- $1 \mathrm{~kg}$ tepung beras

- $\quad$ air mineral secukupnya 
- $10 \mathrm{~g}$ atau 1 bungkus kaldu bubuk

9. Digoreng dengan api yang tidak terlalu besar hingga kuning kecoklatan

10. Ditiriskan dan diamkan selama - +5 menit sampai dingin

11. Siapkan wadah kripik yang telah digoreng dan kripik ditabur bumbu tabur rasa (Balado pedas manis, Balado Hijau, Jagung, BBQ dan Keju)

12. Keripik kulit pisang siap dikemas dengan berat perbungkus $100 \mathrm{~g}$ dan $150 \mathrm{~g}$.

\section{Output}

Output yang kami buat ini adalah beraneka macam rasa olahan kripik dari limbah kulit pisang. Yang akan bekerjasama dengan mahasiswa Universitas Nurul jadid dan untuk dijadikan produk penjualan di warung, took atau even-even campus baik penjualan itu diterima langsung oleh konsumen atau di antarkan kepada konsumen yang sudah memesan lewat media online.

\section{Evaluasi}

Tahap ini yang akan kami lakukan adalah tahap evaluasi yang akan dilakukan pada saat produksi produk kami yang telah selesai. Tahap evaluasi ini berisi laporan pada kegiatan mulai dari tahap pra produksi sampai tahap produksi dengan lama waktu tertentu. Tahap pelaporan ini kami buat dan keuntungan yang didapat, sehingga memperoleh data yang akurat sebagai bahan evaluasi.

Tahap uji kualitas dilakukan setelah tahap-tahap pengolahan selesai, yaitudengan cara melakukan pengecekan terhadap produk yang telah siap untuk di pasarkan.Adapun produk dikatakan telah lolos uji kualitas dan layak jual jika:

\section{Kandungan Gizi}

Berikut ini kandungan gizi kulit pisang dapat dilihat pada tabel :

Tabel 1 Komposisi zat gizi kulit pisang per 100 gram bahan

\begin{tabular}{|c|l|c|}
\hline No. & \multicolumn{1}{|c|}{ Zat Gizi } & Kadar \\
\hline 1 & Air (g) & 68,90 \\
2 & Karbohidrat (g) & 18,50 \\
3 & Lemak (g) & 2,11 \\
4 & Protein (g) & 0,32 \\
5 & Kalsium (mg) & 715 \\
6 & Fosfor (mg) & 117 \\
7 & Zat besi (mg) & 1,60 \\
8 & Vitamin B (mg) & 0,12 \\
9 & Vitamin C (mg) & 17,50 \\
\hline
\end{tabular}

Sumber: Balai Penelitian dan Pengembangan Industri, Jatim, Surabaya (1982). 


\section{SIMPULAN}

Pentingnya pendekatan yang dilakukan oleh Perguruan Tinggi untuk menjawab permasalahan pada masyarakat, agar masyarakat dapat bertumbuh dan berkembang dalam menjalankan usahanya. Program Kemitraan Masyarakat yang dilaksanakan oleh Universitas Nurul Jadid sangat membantu masalah Mitra, dari biasanya kulit pisang di buang, sekarang kulit pisang dijadikan makanan ringan berupa kripik menambah pendapatan UKM kripik pisang, juga membantu cara pemasaran melalui media internet untuk sarana promosi dan hanya mengandalkan jualan melalui konvensional, saat ini Mitra sudah memiliki akun media sosial online yang bisa digunakan sebagai sarana promosi dan juga jualan online. Kegiatan Program Kreatifitas Mahasiswa sangat memiliki dampak perubahan pada Mitra menjadi lebih bersemangat dalam berusaha dan peningkatan pendapatan.

\section{DAFTAR PUSTAKA}

Augesti Alfa, 2018, Jangan dibuang ini 4 khasiat kulit pisang yang jarang diketahui orang, https://www.liputan6.com/global/read/3550612/jangan-dibuang-ini-4-khasiat-kulitpisang-yang-jarang-diketahui-orang

Kurniawan Dian, 2018, Akrobat wiwik sulap kulit pisang menjadi keripik lezat, https://www.liputan.com/regional/read/3684237/akrobat-wiwik-sulap-kulit-pisangmenjadi-keripik-lezat

Peluang usaha keripik kulit pisang, http://www.agrowindo.com/peluang-usaha-keripik-kulitpisang-dan-analisa-usahanya.htm

Balai Penelitian dan Pengembangan Industri, Jatim, Surabaya (1982). 